\title{
The Function of the Press Council in Supporting Legal Protection for Journalists to Actualise the Press Freedom
}

\author{
Suriyanto ${ }^{1}$ \\ ${ }^{1}$ Universitas Jayabaya Jakarta, Indonesia \\ Correspondence: Suriyanto, Universitas Jayabaya Jakarta, Indonesia. E-mail: Correspondent.authot@gmail.com
}

Received: October 20, 2019

Accepted: January 30, $2020 \quad$ Online Published: February 29, 2020

doi:10.5539/jpl.v13n1p104

URL: https://doi.org/10.5539/jpl.v13n1p104

\begin{abstract}
The Press Law established in 1999 as one of the main agenda for reform is a step forward in the effort to actualize press freedom, which is one of the important pillars in a democratic country. The Press Law introduces several things that are intended to strengthen press freedom as well as the quality of journalistic works. Among them are the participation of the community in supervising the press and the functions of the Press Council to receive complaints from the community and to establish and enforce the journalistic code of ethics with the press organization.

However, until now the efforts to continue criminalization against journalists in Indonesia. Law enforcers still do not have a unified view that is in accordance with the spirit of democracy to realize press freedom in Indonesia. This was mainly driven by the practice of state legislation that sets out other laws, such as the ITE Law and the Pornography Law after the Press Law which contains provisions that open multiple interpretations of the provisions of the Press Law. The role of the Press Council in legal protection for journalists has also not been seen and it is as if it has become a new institution that repressed journalists.
\end{abstract}

Keywords: press legislation, press law, press freedom, press council function, journalist protection

\section{Introduction}

Criminalization of journalists is still a real problem in Indonesia to date. This may be due to factors of legal ignorance or due to intentional factors to silence critics voiced by journalists. Some parties still report journalistic work and journalists as well as press companies to the police for an act considered detrimental to themselves or their groups with defamation arguments. Criminal articles of insult and utterance of hatred in the Criminal Code (KUHP) and Law Number 11 of 2008 concerning Information and Electronic Transactions (ITE Law) are often imposed on journalists. In fact, in many cases, the reported news made by journalists and published in the media is a work that meets journalistic principles.

The enactment of Law No. 40 of 1999 concerning the Press became the beginning of independence and freedom of the press in Indonesia, even mentioned in it that freedom and freedom of the press were guaranteed as human rights. The law mentions that the national press is not subject to censorship, banning, or broadcasting bans. It attempts to provide independence for the press to grow without government interference and providing legal protection for the press in carrying out its journalistic duties. However, the existence of the law has not been able to provide protection against press freedom. This is seen by the remain-high level of violence against journalists. Criminalization, censorship and lawsuits against the media are still in place.

There were still many journalists who experienced persecution and were even killed because of the journalistic work they produced. The Alliance of Independent Journalists (AJI) noted that there were 75 cases of violence against journalists occurring in various regions in Indonesia during 2017-2018. The perpetrators were dominated by police followed by government officials. Meanwhile, LBH Press noted that since the institution was established in 2003 to 2017, there have been 732 cases of violence experienced by journalists. (Note 1)

One case that was enough to grab the public's attention was the death of Muhammad Yusuf (MY). A journalist from the media Kemajuan Rakyat and Berantas News, who was found dead at the Kotabaru Class II B Correctional Institution, South Kalimantan, on Sunday, June 10, 2018. He is dead after 15 days occupying Kotabaru prison as a detainee sent by the Attorney Kotabaru Country. He was arrested for reporting the conflict between residents and PT Multi Agro Sarana Mandiri (MSAM) owned by Andi Syamsudin Arsyad aka Haji Isam, 
and was considered to defame MSAM and the businessman. (Note 2)

Therefore, there are several questions to be answered by this paper, namely:

Who is responsible and how is the responsibility for the news that is (considered) detrimental to others? What is the role of the Press Council in protecting journalists and the realization of press freedom? And what causes the ineffectiveness of the provisions of the Press Law to realize press freedom?

\section{The Freedom and Responsibility of the Press}

Freedom of the press - which comes from freedom of opinion, is universal. As guaranteed in Article 19 the United Nations Charter of Human Rights, every person has the right to freedom of expression. In this case, including the freedom to have opinions without interference. Also, to seek, receive, and convey information and ideas through any media regardless of regional boundaries. The guarantee of freedom of speech, opinion and expression is stipulated by the Indonesian national legal framework in the following laws and regulations:

1) Article 28 and Article $28 \mathrm{~F}$ of the 1945 Constitution of the Republic of Indonesia.

2) Decree of the People's Consultative Assembly Number XVII / MPR / 1998 concerning Human Rights Articles 19,20 and 21.

3) Human Rights Law Number 39 of 1999 Article 14 paragraph (1) and (2).

4) Article 2, Article 3 paragraph (1), Article 4 paragraph (1), paragraph (2) and paragraph (3), as well as Article 6 of Law Number 40 of 1999 concerning the Press (Press Law).

In a democratic country, the ultimate power is in the hands of the people. To uphold its sovereignty, the people need to participate in controlling the running of governmental authority. To be able to carry out its supervision, information regarding the administration of government and other functions related to the livelihoods of many people is indispensable. A free press is required to actualize transparency in the administration of state power in all branches. It underlies the theory that an independent media is one of the pillars of a democratic state. (Note 3)

In line with this theory, it is not surprising that history records that oppressive regimes are always featured with various censorship, press bans, books, and art, to perpetuate the power of a government. Therefore, actualizing the press freedom is one of the main agendas for reform, and the Press Law was one of the laws that was first established in the early reform era.

However, the guarantee of press freedom formulated in the Press Law is not unlimited freedom and control. The Press Law also expresses provisions that encourage the press always to produce responsible journalistic works. (Note 4) The responsibility of a free press is a classic and universal concept, as has been stated since 1949 by the Commission on the Freedom of the Press chaired by Robert Hutchins. As a form of responsibility from a free press, there are five conditions proposed, namely: (Note 5)

1) The media must present reliable, complete and intelligent news of daily events in the context that gives them meaning;

2) The press must function as a forum for exchanging comments and criticism;

3) The media must project images that genuinely represent constituent groups in society;

4) The media must present and explain the goals and values of the community;

5) The media must provide full access to hidden information at a time.

In the 1999 Press Law, several important things were introduced and previously unknown, including the participation of the community to participate in activities aimed at developing freedom of the press and guaranteeing the right to obtain the necessary information. These efforts are carried out through activities to monitor and report analyses on legal violations, and technical errors of reporting carried out by the press and submit proposals and suggestions to the Press Council to improve the quality of the national press. (Note 6)

\section{Press Council}

The Press Council was first established through Law Number 11 of 1966 concerning the Principal Provisions of the Press (from now on referred to as Law 11/1966) signed by President Soekarno on 12 December 1966. The functions of the Press Council are by Article 6 paragraph (1) of Law 11/1966 is accompanying the government to jointly foster the growth and development of the national press. The Chairperson of the Press Council is ex-officio held by the Minister of Information. (Note 7)

During the Soeharto era, changes were made to Law 11/1966 through Law Number 21 of 1982 concerning Amendments to Law Number 11 of 1966 concerning Principal Provisions as Amended by Act Number 4 of 1967 
(Note 8) (from now on referred to as Law 21/1982). A significant change in the law is the addition of elements of government representatives, community representatives and experts in other fields (other than the press) in Article 6. (Note 9) The rest of the functions and positions of the Chair of the Press Council are still the same as Law 11/1966.

Fundamental changes occurred in 1999, along with the shift of New Order power to the reform era. Through Law Number 40 of 1999 concerning the Press signed by President Habibie September 23, 1999 (from now on referred to as the Press Law). For the first time the Press Council was declared independent, as stated in Article 15 paragraph (1), "To develop freedom of the press and improve the life of the national press, an independent Press Council was formed". The function of the Press Council which was only merely advising the government in the previous law, amended in Article 15 paragraph (2) of the Press Law to be as follows:

a. to conduct studies for the development of press life;

b. to establish and supervise the implementation of the Journalistic Code of Ethics;

c. to provide consideration and seek settlement of public complaints regarding cases relating to press coverage;

d. to develop communication between the press, the community and the government;

e. to facilitating press organizations in drafting regulations in the field of press and improving the quality of journalist professions; and

f. to maintain a register of press companies.

To carry out this new function, government representatives are not in the membership structure. On the contrary, the aspirations of the press are very intense seen in the composition of membership regulated by Article 15 (3), namely:

a. journalists selected by journalist organizations;

b. the head of the press company chosen by the press company organization;

c. Community leaders, experts in the field of press and or communication, and other areas selected by journalist organizations and press company organizations;

Membership of the Press Council is stipulated through a Presidential Decree, and the Chairperson and Deputy Chairperson are determined or chosen individually among members. (Note 10)

\section{Journalistic Code of Ethics (KEJ)}

In addition to introducing community participation in the development of the press world, the composition of membership and new functions of the Press Council, the Press Law also introduces new obligations for press people to own and obey the KEJ. This does not mean that the KEJ was not known at all in the Indonesian press world. However, the Press Law for the first time determines the obligation of the press to own and obey the KEJ, (Note 11) as well as establish the mechanism for determining and enforcing it. The Journalistic Code of Ethics is agreed upon by journalist organizations and determined and supervised by the Press Council.

\section{Accountability of Journalistic Works}

With the participation of the community to oversee the results of journalistic work, the authority of the Press Council to receive complaints and supervise the implementation of KEJ, it can be said that Indonesia has a legal framework that is complete enough to realize a free and responsible press. It is then interesting to review how accountability for journalistic work in Indonesia should be based on the existing legal framework. For example, using the case of MY which was stated at the beginning of this article.

Hinca IP Panjaitan stated that the Press Law is a special provision governing the implementation of journalistic activities: starting from searching, sorting out, and reporting it to the mechanism for resolving problems arising from press coverage.

a. Whereas technically legal, the press company must appoint the person in charge, which consists of 2 (two) fields, namely, the person in charge of the business sector and the person in charge of the editorial sector. The accountability mechanism carried out by journalists was taken over by the press company represented by the person in charge. (Note 12)

b. By the journalist's code of ethics, by using the fulfilment of the Right to Reply and Correction. This is done by a person or group of people who in this case represents the press company as the person in charge of the editorial department. A person or group of people who feel that their reputation has been harmed due to the news must provide data or facts that are intended as evidence of rebuttal or refutation of the report is incorrect. 
MY was charged with Article 45 A of Law Number 19 of 2016 concerning Amendments to the ITE Law and Article 310 and Article 311 of the Criminal Code. In this case, the Kotabaru Resort Police asked the Press Council for information as an expert in the media according to a memorandum of understanding between the two institutions. (Note 13) This memorandum regulates the mechanism for coordination between the Press Council and the Police to solve complaints on a journalistic work. In this case, the Press Council gave a press statement after MY's death, as follows:

1) The news that was raised in the online media Kemajuan Rakyat and Berantasnews, generally did not meet the technical standards as well as Journalistic Ethics because the information presented in the news, were not tested, balanced and most contained judgmental opinions;

2) Repetitive reporting series with content containing judgmental views without attempts to test and balance the information indicates the existence of bad faith;

3) Repeated reporting that only voices the interests of one party, indicates that the news is not intended for the public interest and is not following the functions and roles of the press as mandated in Article 3 and Article 6 of the Press Law;

4) Those who have been harmed by the series of reports can take legal proceedings by using other laws outside the Press Law. (Note 14)

Based on the statements conveyed above by the Press Council, the criminal process against MY was continued.

The accountability mechanism on the news written by MY in this case should not necessarily be a criminal responsibility as he experienced. PT Multi Agro Sarana Mandiri (MSAM), which is the party claims aggrieved by the news made by MY, should submit a complaint first to the Press Council. It cannot be directly reported with the criminal articles related to defamation. The Press Council on then conducted an examination on the complaint to prove the complainant's' arguments and examine whether the reported news has met the criteria and Journalistic Code of Ethics. Even if, the Press Council was concluding that there were journalistic rules that were not fulfilled by MY, then the Press Council can recommend MY and the media that published the news to make corrections.

If the media refused the recommendation issued by the Press Council, then complainant can submit an official report to the police to settle the case according to the criminal justice system. Even in this process, the Press Council can still be questioned or asked by the Police to clarify the case regarding journalistic work. The council also should be obliged to pay attention to the prescribed standards of journalist professional protection, namely:

a. Legal protection has to be provided for journalists who adhere to the journalistic code of ethics in carrying out their journalistic duties to fulfil the rights of the public to obtain information;

b. In carrying out journalistic tasks, journalists obtain legal protection from the state, society and press companies. Journalistic tasks include seeking, obtaining, possessing, storing, processing, and conveying information through mass media;

c. In carrying out journalistic duties, journalists are protected from acts of violence, deprivation, confiscation of work tools, and may not be inhibited or intimidated by any party;

d. Journalistic work is protected from all forms of censorship;

e. Reporters assigned specifically in hazardous and/or conflict areas must be accompanied by assignment letters, safety equipment that meets the requirements, insurance, as well as knowledge, skills provided by the press companies relating to their assignment interests;

f. In areas of armed conflict, a journalist who has shown their identity as journalists and does not use the identity of the warring parties must be treated as neutral parties and be given legal protection so that they are not intimidated, held hostage, tortured, persecuted, let alone killed;

g. In cases involving journalistic work, the press company has to be represented by an assigned person in charge;

h. In the testimony of cases relating to journalistic work, the person in charge can only be asked about the news that has been published. Journalists can use the right to refuse to disclose to protect their sources of information;

i. The owner or management of a press company is prohibited from forcing journalists to make news that violates the Journalistic Code of Ethics and / or applicable law.

\section{Legislation Related to Press Offences}

Although the stipulation of the Press Law is a step forward in the effort to realize freedom of the press, the 
politics of legislation carried out by the government in the future is not in line with these efforts. After the stipulation of the Press Law, the Government issued several new laws that threatened freedom of opinion and expression. Among them are Law Number 11 of 2008 concerning Electronic Information and Transactions, Law Number 32 of 2002 concerning Broadcasting, Law Number 44 of 2008 concerning Pornography, Law Number 17 of 2011 concerning State Intelligence and Law Number 7 of 2012 concerning Social Conflict Management and the Criminal Law Bill (RKUHP).

As a result of other laws issued after the Press Law, there was a lack of clarity in the resolution of cases relating to press offences. Law enforcers see the presence of the law as an opportunity to interpret different mechanisms for resolving press offences that are further away from legal protection efforts for journalists.

The involvement of the Press Council in the criminal settlement related to the press as introduced by the Supreme Court in the Supreme Court Circular Number 13 of 2008 (SEMA 13/2008), was carried out with the spirit to provide better protection for journalists faced with criminal proceedings. However in its implementation, the Press Council has become a new institution that gives legitimacy to repress the presence of a free press. Moreover, with the existence of the MoU between the Indonesian National Police and the Press Council signed in 2012. (Note 15)

\section{Conclusion}

Based on the above description, it can be concluded that the presence of the Press Law has not been sufficiently able to actualize the press freedom in Indonesia. There are still many weaknesses ranging from the regulatory framework to the implementation by law enforcement that must be corrected.

In the context of legislation, the problems that can be identified are as follows:

1) There is no strict separation of matters which are categorized as press offences and which are not;

2) The existence of the law must be emphasized as a special law (lex specialist) in settlement of cases of press offences;

3) It should be stressed whether the press offence is a complaint offence or a general offence (report offence) because the prosecution period will be different and whether it can be withdrawn or not, and criminal liability must be clarified whether individual or corporation and;

4) Law 40/1999 makes discrimination in criminal proceedings, where if a non-press person commits a violation, then the punishment is confinement and fine (Article 18 paragraph (1)), while the press is only fined (Article 18 paragraph (2) and paragraph (3).

Meanwhile, relating to the perspective of law enforcers in resolving press offences, there are still problems of interpretation on the application of the right to reply and correction as stipulated in Article 5 paragraph (2) of the Press Law. For the press, complaints about a report are resolved through the right of reply and correction; if it is not completed, it can be mediated to the Press Council. While there are some judges who interpret that the aggrieved party can directly submit a criminal report if the media did not fulfil their request to reply and correct a news report.

\section{Notes}

Note 1. Tribunnews.com, Fransiskus Adhiyuda Prasetia. AJI: Kekerasan terhadap Jurnalis Meningkat Rentan Tahun 2017-2018. http://www.tribunnews.com/nasional/2018/05/03/aji-indonesia-kekerasan-terhadap-jurnalis-meningkat-rentan-ta hun-2017-2018. Accessed on 13 August 2018.

Note 2. Banjarhits.id., Tim. Kronologi Tewasnya Wartawan yang Dijebloskan ke Penjara. https://kumparan.com/banjarhits/kronologi-tewasnya-wartawan-yang-dijebloskan-ke-penjara. Accessed on 10 June 2018.

Note 3. Pranowo, Bambang M. Multidimensi Ketahanan Nasional/Multidimentional of National Resilience. Pustaka Alvabet: 2010. P. 126, first paragraph of general explanation of Press Law.

Note 4. Indonesia. Undang-Undang Nomor 40 Tahun 1999 tentang Pers/Law Number 40 Year 1999 on Press. Explanation Section, Sub Section I: General, paragraph 5.

Note 5. Ali Sodikin, Four Theories of the Press. http://angintimur147.blogspot.com/2012/10/teori-pers.html. Accessed on 28 October 2017. 
Note 6. Article 17 paragraph (1), (2) and (3) Press Law.

Note 7. Article 7 paragraph (1) Law Number 11/1966.

Note 8. Law Number 4/1967 only adding the provisions of Article 21 paragraph (2) of Law 11/1966 which states that the rules of the Presidential Decree Number 4/1963 concerning safeguards of printed goods whose contents could disrupt public order, especially regarding bulletins, daily newspapers, magazines and periodical publications - are not valid.

Note 9. The previous law only explained "members of the Press Council consist of representatives of press organisations and experts in the press area".

Note 10. Article 15 paragraph (4) and (5) Press Law.

Note 11. Article 7 paragraph (2) Press Law.

Note 12. Pandjaitan, Hinca I.P., Menegakkan Kemerdekaan Pers, "1001" Alasan Undang-Undang Pers Lex Specialis: Menyelesaikan Permasalahan Akibat Pemberitaan Pers/Upholding the Freedom of the Press, "1001" Reasons Why the Press Law is Lex Specialis: Settling Down Cases from A Press Report. Serikat Penerbit Surat Kabar: 2004.

Note 13. The Indonesian National Police and the Press Council have a MoU signed in February 2012. According to the two institutions, this $\mathrm{MoU}$ aims to improve the quality of pre-investigations, investigations and settlements of alleged criminal acts due to press coverage, and clarify the mechanism for providing Press Council assistance to the National Police related to providing information as an expert. See http://www.tribunnews.com/nasional/2012/02/10/ini-isi-mou-dewan-pers-dengan-polri. Accessed September 1, 2018.

Note 14. Aji, M. Roseno. Dewan Pers Cek Kasus Pidana Wartawan yang Ditahan di Kotabaru/The Press Council Checked the Criminal Cases of Journalists Detained in Kotabaru. https://nasional.tempo.co/read/1097356/dewan-pers-cek-kasus-pidana-wartawan-yang-ditahan-di-kotabaru/full\& view=ok. Accessed on 1 September 2018.

Note 15. Standard on the Protection of the Journalists. https://www.dream.co.id/kode-etik/standar-perlindungan-profesi-wartawan.html, Accessed on 14 August 2018. This standard was approved and signed by a number of press organizations, leaders of press companies, press figures, related institutions, and the Press Council in Jakarta, April 25, 2008. Before being passed, the draft of the Journalists' Professional Protection Standards was discussed through a series of discussions held by the Press Council.

\section{Copyrights}

Copyright for this article is retained by the author(s), with first publication rights granted to the journal.

This is an open-access article distributed under the terms and conditions of the Creative Commons Attribution license (http://creativecommons.org/licenses/by/4.0/). 